\title{
Studies on nutritional composition and characterization of lipids of Lates calcarifer (Bhetki)
}

\author{
T. Pervin ${ }^{a}$, S. Yeasmin ${ }^{\text {a }}$, R. Islam*a ${ }^{* a m r u z z a m a n}{ }^{\text {b }}$, A. Rahman ${ }^{a}$, and A. Sattar ${ }^{a}$ \\ ${ }^{a}$ Department of Applied Chemistry and Chemical Technology, Islamic University, Kushtia, Bangladesh \\ ${ }^{b}$ Department of Applied Nutrition and Food Technology, Islamic University, Kushtia-7003, Bangladesh
}

\begin{abstract}
Physico chemical characteristics of lipids extracted from Lates calcarifer and nutritional composition of that fish were analyzed by standard method. The coefficient of viscosity was 447.69 millipoise at $30^{\circ} \mathrm{C}$ and specific gravity and refractive index were 0.98 and 1.37 at $30^{\circ} \mathrm{C}$ respectively. Saponification value, saponification equivalent, iodine value, peroxide value, acid value, ester value and reichert-meissel value were found 95.50, 286.96, 62.81, 52.59, 1.83, 193.67 and 2.94 respectively. Percentage of free fatty acid, unsaponificable matter and cholesterol were found $0.92,1.86$ and 13.74 respectively. Further, carbohydrate, protein, lipid, moisture, ash and dry matter content of $L$. calcarifer were found $0.93,23.5,5.7,70,5$ and $30 \%$ respectively. The fish was found to contain 580, 270,140, 120 and $9 \mathrm{mg}$ of Na, K, Ca, $\mathrm{Mg}$ and $\mathrm{Fe}$ per $100 \mathrm{~g}$ respectively. However $\mathrm{Cu}$ and $\mathrm{Zn}$ were found to present in negligible amount. The fatty acid profiles $L$. calcarifer were identified by GLC method. Among fatty acid lauric, palmitic, oleic and stearic were found to present 4.49, 52.86, 36.88 and 5.75\% respectively.
\end{abstract}

Keywords: Lates calcarifer; Lipid; Fatty acid composition; GLC; Mineral content

\section{Introduction}

Most of the people in the developing countries are dependent on fish as a source of animal protein. It has been estimated that about $80 \%$ of the animal protein in the diet of the people of Bangladesh are contributed by fish (Hawk and Oser, 1965). L. calcarifer is a fresh water fish species commonly known as Barramundi and in Bangladesh, locally known as Bhetki. It is also known as Asian Seabass, is a species of catadromous fish in family Latidae of order Perciformes. The native species is widely distributed in the Indo-West Pacific region from the Persian Gulf, through Southeast Asia to Papua New Guinea and Northern Australia. Fish is inseparable part of the Bangladesh economy and it plays a vital role in nutritional balance as an important source of protein. Besides protein, fish is a good source of carbohydrate, fat, vitamin and mineral. Nutrients needed in relatively large quantities are called macronutrients and those needed in relatively small quantities are called micronutrients (Annymous, 1986). Fish liver oil is good source of vitamin A and D. Some B complex vitamins are also found in fish.

L. calcarifer contains polyunsaturated fatty acids (PUFA) enriched of omega-3 fatty acid, which play important roles in cardiovascular system to reduce the risk of heart attack (Islam, 1983). Omega-3 fatty acids are helpful to reduce cholesterol level in blood and helpful in the prevention of hyperlipidemia, secondary cardiovascular disease and high blood pressure. The nature and quantity of lipid in fish are dependent on species and habitats. Fish lipids are the main sources of polyunsaturated fatty acids (PUFAs) especially eicosapentaenoic acid (EPA; $\mathrm{C}_{20: 5)}$ and docosahexaenoic acid (DHA; $\mathrm{C}_{22: 6}$ ) (Osman et al, 2001). These two fatty acids cannot be synthesized by the human body (essential fatty acid) and must be obtained from the diet (Linko and Hayakawa, 1996). Lipids and fatty acids also play a significant role in membrane biochemistry and have direct effect on the membrane-mediated process in human such as osmoregulation, nutrient assimilation and transport (Ibrahim et al, 2004).

In this study, nutritional composition of $L$. calarifer was analyzed and lipid was extracted, characterized and fatty acid composition was determined by gas liquid chromatography (GLC).

* Corresponding author: E-mail: rafiq.acct@gmail.com 


\section{Materials and methods}

\section{Sample Collection}

About 500 gm of fish (L. calcarifer) were collected from market of Binodpur, Rajshahi, Bangladesh. Prior to analysis, the internal organs were removed and the fish was washed to remove the residual blood. Fish fillet was obtained by cutting the fish lengthwise along the backbone to obtain maximum amount of flesh without including the backbone. The fillet was cut into small pieces.

\section{Proximate composition analysis}

The moisture, carbohydrate, protein, ash and dry matter contents of the sample were determined by the AOAC methods (AOAC, 1990). The experiments were performed in triplicate and values are expressed as mean \pm standard deviation.

\section{Mineral Analysis}

Minerals analysis of fish sample were done according to the AOAC method (AOAC, 1995), using Atomic Absorption Spectrophotometer.

\section{Extraction and estimation of total lipids}

Total lipids were extracted from fish muscle tissue samples and estimated according to Folch et al. (1957). Briefly, a chloroform/methanol solvent mixture $(2: 1, \mathrm{v} / \mathrm{v})$ was added to samples in the ratio solvent/tissue of 20:1 (v/w). The samples were homogenized three times and each homogenization step was followed by cooling of the sample for $1 \mathrm{~h}$ at $4{ }^{\circ} \mathrm{C}$. The chloroform/methanol extracts were incubated overnight at $4{ }^{\circ} \mathrm{C}$ to allow the organic (containing the extract of total lipids) and aqueous layers to separate completely. The upper (aqueous) layer was removed, and the lower (organic) layer was rinsed with chloroform/methanol $(2: 1 \mathrm{v} / \mathrm{v})$, then placed into a glass tube. The total lipid fraction was obtained by evaporating the lower phase. The solvent was removed in a rotary evaporator under vacuum at $40{ }^{\circ} \mathrm{C}$. These extracts, representing the total lipids, were weighed, and results were noted. The resulting extract of total lipids was stored at $4{ }^{\circ} \mathrm{C}$ until further analysis.

\section{Characterization of the Lipid}

Physical and chemical properties of the lipid extracted from L. calcarifer were determined by standard method (Bockenooge, 1964, Jayaraman, 1981; Williams, 1966).

Preparation of the methyl ester

The samples lipids were converted to their constituent fatty acid methyl esters (FAME) according to standard method (Loury, 1967; Randerath, 1966). 5g lipid was taken in a round bottom flask $(125 \mathrm{~mL})$ and saponified with alcoholic potassium hydroxide solution $(50 \mathrm{~mL})$. The mixture was then refluxed for 45 minutes on a water bath until it became clear. The reaction mixture was allowed to cool and then neutralized with $\mathrm{HCl}(5 \mathrm{~N})$. Alcohol was removed from the neutralized solution by evaporation over a steam bath. $25 \mathrm{~mL}$ water was added to this alcohol free solution and $\mathrm{pH}$ of the solution was adjusted to 1-2 drops by adding concentrated $\mathrm{HCl}$. The acidified aqueous mixture was then extracted with $20 \mathrm{~mL}$ of ether in a separating funnel and the extraction was repeated for three times. The combined ether extract was washed with water in order to remove any adhering $\mathrm{HCl}$. Ether was then removed from the extract to give the fatty acid mixture. The fatty acid mixture was then esterified with methanolic solution of sulfuric acid $(0.25 \mathrm{M}, 5 \mathrm{~mL} / \mathrm{gm}$ acid $)$. After esterification, the mixture was dissolved in ether $(25 \mathrm{~mL})$ in a separating funnel and was washed with dilute sodium carbonate solution until the effervescence ceased. It was then washed with water, dried over anhydrous sodium sulfate and finally ether was removed to give methyl ester mixture.

\section{Gas liquid chromatographic analysis of methyl esters}

Analysis of methyl ester was carried out with a "PUE UNICAM" $4500 \mathrm{U}$ model gas chromatograph equipped with a flame ionization detector (Kanella et al., 1977; Hossain et al., 1988; Huq et al, 1979). A glass coiled column (3mm I.D. $2.1 \mathrm{~m}$ ) packed with 70-100 mesh chromosorb after impregnating it with $10 \%$ diethylene glycole succinate was used for the regular packed column GLC. The temperature programming in the oven was from $130{ }^{\circ} \mathrm{C}$ to $230{ }^{\circ} \mathrm{C}$ with the rate of rising $4{ }^{\circ} \mathrm{C}$ per minute. The oven, injector and detector temperature were $190{ }^{\circ} \mathrm{C}, 200^{\circ} \mathrm{C}$ and $205^{\circ} \mathrm{C}$ respectively with a nitrogen carrier gas flow rate $30 \mathrm{~mL} /$ minute. The speed of the chromatogram was at $0.5 \mathrm{~cm} /$ minute. The fatty acids in 
the mixture were identified by comparing its relative retention volume (Gurr and James, 1975). The area of each chromatogram peak was determined by multiply the height of the peak by the width of the peak at one-half of the height.

\section{Results and discussion}

\section{Proximate composition}

Mean percentage of proximate composition of $L$. calcarifer were shown in Table I. Moisture content of $L$. calcarifer was $70 \pm 2.8$, which was found similar as reported by Hui, 2001 . The percentage of water is a good indicator of its relative contents of energy, proteins and lipids. The lower the percentage of water, the greater the proteins and lipids contents

\section{Table I. Proximate composition of Lates calcarifer (Bhetki)}

\begin{tabular}{lc}
\hline Parameters & Percentage (\%) \\
\hline Moisture & $70 \pm 2.8$ \\
Dry matter & $30 \pm 0.8$ \\
Ash & $5 \pm 0.24$ \\
Carbohydrate & $0.93 \pm 0.12$ \\
Lipid & $5.7 \pm 0.3$ \\
protein & $23.5 \pm 0.16$ \\
\end{tabular}

*Values are expressed as the mean \pm standard deviation $(\mathrm{n}=3)$.

and higher the energy density of the fish (Dempson et al., 2004). Gray eel-catfish was found to contain the highest level of moisture among the demersal fish studied, with value of $81.66+1.47 \%$ compared to other fish that ranged between $75 \%$ and $80 \%$ (Nurnadia et al., 2011). Dry matter content was found $30 \pm 0.8$. Moisture and Dry matter content are inversely related to each other. Dry matter content was found $5 \pm 0.24 \%$. Ash content was found $5 \pm 0.24$, which was similar to wild feather back fish (Naeem et al., 2011) and higher than catfish (Olayemi et al., 2011). Protein and fat are the major nutrients in fish and their levels help define the nutritional status of the particular organism. Protein and fat content of $L$. calcarifer were found $23.5 \pm 0.16$ and $5.7 \pm$ $0.3 \%$ respectively. Fat composition exhibited seasonal variations in all species of fish. Biological values of proteins are high and it contains all essential amino acids and fish fat also contains essential fatty acids and omega-3 fatty acids. According to Ackman 1967, L. calcarifer is a medium fat content fish (4-8\%). Protein content of Bramundi was found similar to that of Long-tailed butterfly ray and higher than that of Gray eel-catfish and Cuttlefish (Nurnadia et al., 2011).

\section{Mineral Composition}

The results of the percentage means of mineral elements concentrations were given in Table II. Among the mineral elements investigated, concentration of sodium $(\mathrm{Na}+)$ in $L$. calcarifer were observed to have appreciably dominated $(580 \mathrm{mg} / 100 \mathrm{gm})$ following potassium, calcium, magnesium and iron. The levels of sodium found in Bhetki fish is much higher than those measured in sea bass by Abdullah et al. (2011). Sodium regulates the electrolyte and acid-alkali balances, the conductive capacity of the nerves, muscle contractions and the production of adrenaline and amino acids (Pirestani et al., 2009). The concentration of potassium

Table II. Mineral composition of Lates calcarifer (Bhetki)

\begin{tabular}{lc}
\hline Mineral & Content $(\mathrm{mg} / 100 \mathrm{gm})$ \\
\hline Sodium $(\mathrm{Na})$ & $580 \pm 0.65$ \\
Potassium $(\mathrm{K})$ & $270 \pm 0.34$ \\
Calcium $(\mathrm{Ca})$ & $140 \pm 0.19$ \\
Magnesium $(\mathrm{Mg})$ & $120 \pm 0.45$ \\
Iron $(\mathrm{Fe})$ & $9 \pm 0.11$ \\
Copper $(\mathrm{Cu})$ & $\operatorname{tr}$ \\
Zinc $(\mathrm{Zn})$ & tr \\
\hline
\end{tabular}

*Values are expressed as the mean \pm standard deviation $(n=3)$. tr means traces amount

$\left(\mathrm{K}^{+}\right)$in the fish samples examined ranked second among the mineral elements analyzed. This tends to disagree with the work done by Onyia, et al. (2010) at Nigeria. Potassium content of $L$. calcarifer was found similar to $S$. lucioperca (Pirestani et al., 2009). Ca content was found slightly higher than $R$. frisii kutum (Esmailzadeh et al., 2004). Bhetki can be a good source of calcium for the human body, considering the suggested daily calcium intake amount of $800 \mathrm{mg} /$ day (Whithney and Rolfes, 2008). Magnesium content was found $120 \mathrm{mg} / 100 \mathrm{gm}$ in Bheki fish. An adequate intake of magnesium has some useful roles in a human body due to the fact that it regulates enzyme systems, helps to maintain bone 
health, is required for energy metabolism, and acts as a part of the protein-making machinery in all cells of soft tissues (Whithney and Rolfes, 2008). Copper and zinc were present in trace amount. Copper and zinc are essential for good health, but very high intakes can cause health problems such as liver and kidney damage (Atsdr, 2004). The concentration of minerals in fish muscles examined could have been as a result of the rate in which they are available in the water body and the ability of the fish to absorb these inorganic elements from their diets and the water bodies where they live (Adewoye and Omotosho, 1997). Iron content of L. calcaifer $(9 \pm 0.11)$ was found similar to Rohu fish $(9.9 \pm 0.13)$ as reported by Jyothirmayi et al. (2009). Some other fishes like bass, cod, salmon, and halibut are good source of iron containing 4.2, 9.4, 8.6 and $9.5 \mathrm{mg} / 100 \mathrm{gm}$ respectively (Gehring et al. 2011).

\section{Fat and Fatty acid Composition}

The lipid from the fish was extracted by solvent extraction process using chloroform-methanol mixture as an extracting

Table III. Physical constants of the lipid of Lates calcarifer

\begin{tabular}{ll}
\hline Physical constant & Value \\
\hline Specific gravity at $30{ }^{\circ} \mathrm{C}$ & 0.98 \\
Refractive index at $30{ }^{\circ} \mathrm{C}$ & 1.37 \\
Co-efficient of viscosity (milipoise) & 447.69 \\
\hline
\end{tabular}

Table IV. Chemical constants of the lipid of Lates calcarifer

\begin{tabular}{ll}
\hline Chemical constants & Value \\
\hline Saponification value & 95.50 \\
Ester value & 193.67 \\
Iodine value & 62.81 \\
Peroxide value & 52.59 \\
Reichert-Meissel value & 2.94 \\
Acetyl value & 15.94 \\
Saponification equivalent & 286.96 \\
Percentage of free fatty acid & 0.92 \\
Unsaponifiable matters (\%) & 1.86 \\
Acid value & 1.83 \\
Cholesterol value (\%) & 13.74 \\
\hline
\end{tabular}

solvent. It was found that the fish contained 5.7\% lipid A number of physical and chemical tests were employed to identify the nature of oils and fats. The chemical constants are more important to characterize an oil or fat, yet the physical constants are also often capable of expressing valuable information. These constants of the lipid of $L$. calcarifer are given in Table III and Table IV.

The refractive index of fats and oils depends to some extent on their unsaturation (Peach and Tracy, 1995) and the higher refractive index represents higher unsaturation. The refractive index of fish L. calcarifer $\left(137\right.$ at $\left.30^{\circ} \mathrm{C}\right)$ is slightly lower than the range of standard value of $1.4-1.473$ for fishes (Abdulkadir et al., 2010). The specific gravity of particularly all fats and oils lies between $0.90-0.95$. The specific gravity obtained in the present study $\left(0.98\right.$ at $\left.30{ }^{\circ} \mathrm{C}\right)$ is slightly higher than the normal range.

Iodine value gives an estimate of the degree of unsaturation and so of the relative amounts of unsaturated fatty acids in the triglyceride molecules of the fat. Iodine value of Bhetki fish was found 62.81, which was lower than Lepidocephalus guntea (96.05) and Soybean oil (129.00) ( Islam, 2008). The percentage of free fatty acid (above $1.5 \%$ ) is a determination or indication of unsuitability of the lipid for given edible purpose. So the fish lipid might be suitable for edible purpose.

Table V. Fatty acid percentages derived from methyl ester mixture of Lates calcarifer (by GLC analysis)

\begin{tabular}{llll}
\hline Ret. Time & Area & Name of fatty Acid & Rel.\% \\
\hline 9.71 & 412 & C12:0 (Lauric) & 4.49 \\
13.07 & 4842 & C16:0 (Palmitic) & 52.86 \\
15.97 & 3378 & C18:1 (Oleic) & 36.88 \\
16.46 & 527 & C18:0 (Stearic) & 5.75 \\
\hline
\end{tabular}

The unsaponifiable matter amounting to $0.45-2.0 \%$ represents a mixture of several lipid classed, viz, sterols, tocopherols, hydrocarbons, higher aliphatic and terpenoid alcohol. The unsaponifiable matter in the lipid was found to be $1.86 \%$, which indicates that lipid, also contained sterols, tocopherols, hydrocarbons etc. The higher the saponification value, the lower the average molecular weight (O'Brien, 1998). Saponification equivalent is directly proportional to the average chain length of fatty acid present. Fats or oils 
consisting largely of $\mathrm{C}_{18}$ fatty acids along with some myristic, palmitic acids, a little unsaponifiable matter and a low free acidify generally have a saponification equivalent around 290.80; higher value indicates the presence of appreciable quantity of higher acids (Carrol and Noble, 1957). The present result (286.96) clearly indicated that the lipid contained mainly fatty acids of $\mathrm{C}_{18}$ molecular weight along with some palmitic acid.

Fatty acid analysis of the lipid was carried out by GLC after trans-esterification of the glycerides to their methyl esters. The refractive index of fats oil depends to some extent on their unsaturation (Peach and Tracy, 1995) and the higher refractive index represents higher unsaturation. The stationary phase used in the column was the polar polyester $10 \%$ DEGS (Diethylene glycol succinate) with its packing materials (gas chromp. 100-120 mesh). The identification of fatty acid components from GLC analysis was carried out on the basis of relative retention time and was quantified by measuring the peak area in comparison with standard fatty acid. The fish lipid contained highest amount of palmitic acid (52.86\%), while lauric acid, oleic acid and stearic acid were found $4.49,36.88$ and $5.75 \%$ respectively.

From the findings of the present investigation, it may be suggested that the lipid is suitable for edible purpose as it contained higher amount of unsaturated fatty acids. These unsaturated fatty acids always play important roles in the metabolism of living organism (Hawk and Oser, 1965). High level of unsaturated fish lipid is found to inhibit the activity of HMG-CoA reductase (Ide et al, 1978; Siscovick et al 1995) which is the regulatory enzyme in cholesterol biosynthesis. Due to the biosynthesis of cholesterol in liver, PUFA plays an important role in maintaining the blood cholesterol level

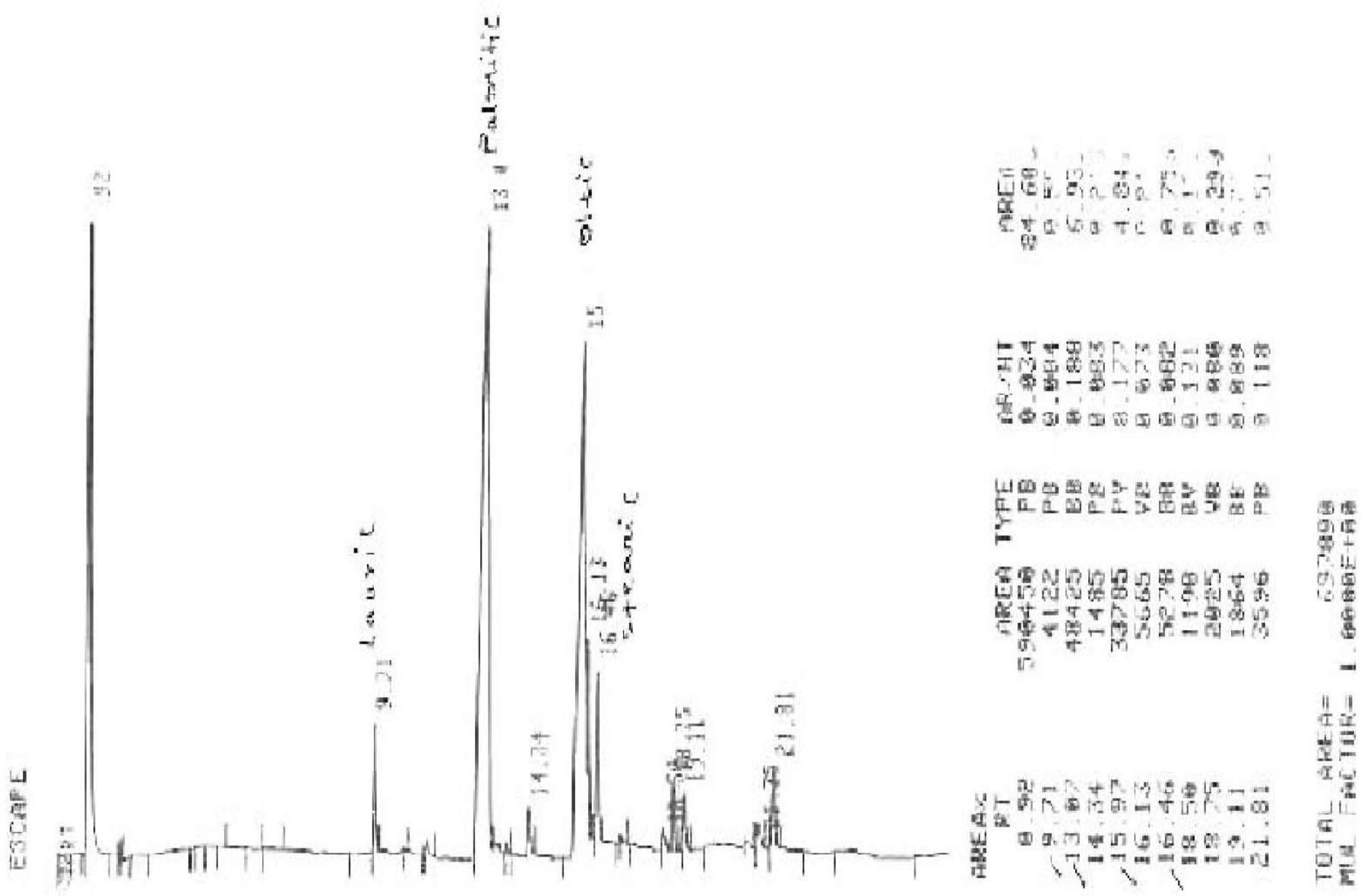

Fig. 1. Fatty acid composition of the methyl ester mixture derived from the lipid (by GLC analysis) 
normal (Nestel, 1990). Lipid content and fatty acid composition of marine fishes are differ among species, sex, age, size, reproductive status, geographic location and season (Pigott and Tucker, 1990).

\section{Conclusion}

Barramundi are catadromous fish and is native to the tropical waters of northern Australia, Southeast Asia, and southern China. From the current study it can be concluded that due to the presence of appreciable amount of protein, fat, mineral and fatty acid, this fish and fish products such as fish burger, fish cake and fish crackers and also for use in controlling diet while the wastes recovered can be used for fish meal or silage production for animal feeds. Hence, they are suitable as potential industrial material for possible utilization for different products.

\section{Acknowledgement}

This research project was supported by the Faculty of Science \& Technology, Islamic University, Kushtia, Bangladesh. Besides, we are grateful to Organic Chemistry Laboratory, University of Dhaka for supporting GLC analysis.

\section{References}

Abdullah O, Ayse O and Senol K (2011), Fatty Acid Composition and Mineral Content of Upeneus moluccensis and Mullus surmuletus, Turkish J. of Fish and Aqua. Scie., 11: 69-75.

Abdulkadir M, Abubakar GI and Mohammed A (2010), Production and characterization of oil from fishes, ARPN J. of Engin. and App. Sci., 5(7): 769-776

Ackman RG (1967), Characteristics of the fatty acid composition and biochemistry of some fresh-water fish oils and lipids in comparison with marine oils and lipids. $J$. Com. Biochem. and Physiol., 22(3): 907-922.

Adewoye SO and Omotosho JS (1997), Nutrient Composition of some freshwater fishes in Nigeria Biosci. Res. Commun. 11 (4) 333-336.
Annymous, (1986), Cholesterol metabolism and omega-3 polyenes in fish oil, Nutrition Reviews. 4(147): PMID:2872641

AOAC (1990), Official Methods of Analysis. 14th ed. Association of Official Analytical Chemists, Arlington, VA.

AOAC (1995), Official Methods of Analysis, 16th E.D. (Association of Analytical Chemists, Arlington, VA.

Atsdr (2004), Agency for Toxic Substances and Disease Registry, Division of Toxicology, Clifton Road, NE, Atlanta, GA. Available from http://www.atsdr.cdc. gov/toxprofiles/.

Bockenooge HA (1964), Analysis and characterization of oil, fats and fat products, 1:27.

Carrol KK and Noble RL (1957), Influence of a dietary supplement of erucic acid and other fatty acids on fertility in the rat. Can. J. Biochem. Physiol. 35: 1093.

Depmson IB, Schwarz CJ and Shea M (2004), Comparative proximate body Atlantic salmon with emphasis on parr from fluvial and lacustrine habitats, J. Fish Biol., 64: 1257-1271.

Esmailzadeh Kenari R, Sahari MA and Motamedzadegan A (2004), Comparative study on nutrient of kutum (Rutilus frisii kutum) and grass carp (Ctenopharyngodon idella) and their marinade qualities. 2nd International Congress on Aquaculture, Fisheries Technology and Environmental Management. Athens, Greece, E.U.

Folch J, Lees M and Sloane Stanley GH (1957), A simple method for the isolation and purification of total lipides from animal tissues. J. Biol Chem, 226(1): 497-509.

Gehring CK, Gigliotti JC, Moritz JS, Tou JC and Jaczynski $\mathrm{J}$ (2011), Functional and nutritional characteristics of proteins and lipids recovered by isoelectric processing of fish by-products and low value fish. J. Food Chem. 124(2): 422-431. 
Gurr MI and James AT (1975), Lipid Biochemistry. Chapman and Hall, London Second Edition. 12: 78.

Hawk and Oser BL (1965), Hawk's Physiological Chemistry. Tata McGraw-Hill Publishing Company. Ltd. BombayNew Delhi. Fourth Edition. pp.1472.

Hawk and Oser BL (1965), Hawk's Physiological Chemistry. Tata McGraw-Hill Publishing Company. Ltd. BombayNew Delhi. Fourth Edition. pp.1364-1365.

Hossain MA, Alam M and Hoq MS (1988), Studies on the Composition of Ipillpil (Leucaena Leucocephala) Seed Oil. Dhaka University Studies. 36(2):165.

Hui YH (2001), Meat Science and Application, CRC Press, pp.704.

Huq MS, Khan MS and Rubbi SF (1979), Determination of Chain Length and Degree of Unsaturation of Fatty acid Composition of Hilsha Fish Oil by Argentation Chromatography and Gas Liquid Chromatography. Bangladesh J. Sci. Ind. Res., 1(2): 159-169.

Ibrahim HI, Bayir A, Sirkecioglu AN, Aras NM and Atamanalp M (2004), Comparison of Fatty Acid Composition in Some Tissue of Rainbow Trout (Oncorhychus mykiss) Living in Seawater and Freshwater, Food Chemistry., 86: 55-59.

Ide I, Okamatsu H and Sugano M (1978), Regulatio by dietary fats of 3-hydroxy-3-methyl glutrayl coenzymeA reductase in rat liver, J. Nutr., 108 (4): 601-612.

Islam A (1983). A report on Aquatic Culture, Bangladesh Fisheries Resources Survey System., 1:28.

Islam S, Hossain T, Alam, MT and Habib R, (2008), Physico-chemical behavior of the fish lipid from Lepidocephalus guntea (Hamilton) and variation of Lipid profile with size, Pak. J. Biol. Sci., 11: 13421347.

Jayaraman J (1981), Laboratory Manual in Biochemistry, Wiley Eastern Ltd. New Delhi, India, pp.97.
Jyothirmayi J, Balaswamy K, Prabhakara Rao PG, Narsing Rao G and Rao DG (2009), Physico-chemical composition and functional properties of roes from some fresh water fish species and their application in some foods, E. J. E. A. F. Chem., 8(8): 704-710.

Kanella JE, Shimp LE, Mai J and Weihranch (1977), Fatty acid content and composition of freshwater finfish. $J$. Am. Oil. Chemist. Soc., 54: 425.

Linko YY, and Hayakawa K (1996), Docosahexaenoic Acid: A Valuable Nutraceutical?, Trends in Food Sci. \& Tech., 7: 59-62.

Loury M (1967), A general method for rapid conversion of fats to methyl esters. Revue Franc. Corps. Gras. 1967. 14(6): 383

Naeem M, Rasul A, Salam A, Iqbal S, Ishtiaq A, Khalid M and Athar M (2011), Proximate analysis of female population of wild feather back fish (Notopterus notopterus) in relation to body size and condition factor, Afri. J. of Biotech., 10(19): 3867-3871.

Nestel PJ (1990), Effects of omega-3 fatty acid on lipids metabolism, Аnпи. Rev. Nutr., 10:149-167.

Nurnadia AA, Azrina A and Amin (2011), Proximate composition and energetic value of selected marine fish and shellfish from the West coast of Peninsular Malaysia, Intern. Food Res. J.1 18: 137-148.

O'Brien RD (1998), Fats and Oils: Formulating and Processing for Application, Lancaster: Technomic Publishing Co. Inc.

Olayemi FF, Adedayo MR, Bamishaiye EI and Awagu EF (2011), Proximate composition of catfish (Clarias gariepinus) smoked in Nigerian stored products research institute (NSPRI): Developed kiln, Intern. J.Fish. and Aquacul., 3(5): 96-98.

Onyia LU, Milam C, Manu JM and Allison DS (2010), Proximate and mineral composition in some freshwater fishes in upper river Benue, Yola, Nigeria., Conti. J. Food Sci. and Tech., 4: 1- 6. 
Osman H, Suriah AR and Law EC (2001), Fatty Acid Composition and Cholesterol Content of Selected Marine Fish in Malaysian Waters, Food Chem, 73: 5560.

Peach K and Tracy MV (1995), Modern method of plant analysis springer verlog, Newyork, 2: 332

Pigott GM and Tucker BW (1990), Seafood Effects of Technology on Nutrition, New York: Marcel Dekker Inc.

Pirestani S, Ali Sahari M, Barzegar M and Seyfabadi SJ (2009), Chemical compositions and minerals of some commercially important fish species from the South Caspian Sea, Intern. Food Res. J. 16: 39-44.

Randerath K (1966). Thin Layer Chromatography, Academic Press, New York. 21: 235.
Siscovick DS, Ragunathan TE, King I, Weinmann S, Wicklund KG, Albright J, Bovbjerg V, Arbogast P, Smith H and Kushi LH. et al. (1995), Dietary intake and cell membrane leve;s of long-chain omega-3 polyunsaturated fatty acids and the risk of primary cardiac arrest JAMA, 274: 1363-1367.

Whithney E and Rolfes SR (2008), Water and Major Minerals and The Trace Minerals. Understanding nutrition, 11th Ed. West Publishing Company, MN, USA: 396-475.

Williams KA (1966), Oils, Fats and Fatty foods, Fourth Edition, J \& A. Churchil Ltd. London,pp.124.

Received: 31 January 2012; Revised: 13 July 2012; Accepted: 11 July 2012. 